\title{
Islamic Expression of Wali Mosque Interior and Architecture in Indonesia
}

\author{
Budiono $^{1}$, Murni Rachmawati ${ }^{2}$, Endang Titi Sunarti Darjosanjoto ${ }^{3}$, Muhammad Faqih ${ }^{4}$ \\ ${ }^{1}$ Student of Doctoral Program, Department of Architecture, Institut Teknologi Sepuluh \\ Nopember (ITS), Surabaya, Indonesia \\ 2,3,4 Senior Lecturer, Department of Architecture, Institut Teknologi Sepuluh Nopember (ITS), \\ Surabaya, Indonesia \\ ${ }^{1}$ budiono@interior.its.ac.id, . ${ }^{2}$ murniach@arch.its.ac.id
}

\begin{abstract}
There are two main approaches to understanding Islamic Design and Architecture. First, an approach that emphasizes the object as a product of thought. Second, the approach by looking at Islamic ideas, values, and principles through religious sources and not speaking within the framework of objects. In the second approach, the values and principles of Islam expressed through the composition of forms and spaces in buildings. This study aims to find patterns and variations in the implementation of Islamic values and principles in the exterior and interior of buildings, especially mosque building. Case studies are several Wali mosques in Indonesia. Data obtained from physical observations, interviews, and visual documentation. The analysis conducted with an interpretive method that describes the physical characteristics and meanings of some study objects in-depth. This paper can conclude that Islamic expressions those related to the value of transcendence or the remembrance of monotheism can be found in Wali mosque and mausoleum. The results of this study are expected to be used as input for further studies on the search for 'forms' in Islamic design and architecture, especially the form of mosques in Indonesia.
\end{abstract}

Keywords: form, Islamic architecture, Islamic value, object, meaning,

\section{INTRODUCTION}

Mosque architecture is a cultural work of Muslims. Mosque architecture is a prime example of what called Islamic Architecture. The approaches and studies that have been carried out to understand Islamic architecture classified into two categories of approaches. The first approach emphasizes more on the object as a product of thought or more based on the discussion and framework of thought to objects that are products of Islamic society. This approach leads to a discussion of building objects that are more of an image-forming and are often not based on a basic understanding of the community, place, and time that forms the background. A second approach is an approach by looking at Islamic ideas, values, and principles through religious sources. An approach does not speak in terms of objects, but It speaks a broader context in the understanding of ideas and values [1]. Some Muslim intellectual figures who have ideas that are in line with this second approach include Seyyed Hossein Nasr and Ismail Raji Al-Faruqi. Seyyed Hossein Nasr argues that the important aspect of the creation of Islamic art, design, and architecture is a religious aspect called Islamic 
Spirituality. There needs to be a spirituality and sufism approach in looking at elements of design and architecture. Because Islamic art produced from the depth dimension of Islam, it will bring people to the essence of their faith. Specifically, Islamic Syariah does not provide guidelines for the development of Islamic art, including Islamic design and architecture [2]. Ismail Raji Al-Faruqi sees Islam as an integral, progressive, and comprehensive system of life. According to Al-Faruqi, aesthetic is the view that emerged from the Tauhid worldview, which is the core of Islamic guidance, which can bring an observer's awareness of the idea of transcendence. Aesthetics in the concept of Islamic art, according to Al-Faruqi, does not stop merely at the aesthetics of physical form but has meaning and function as a reminder of tauhid. Tauhid means the ontological separation between God and the entire natural field. Muslim artists believe that nothing in nature can reveal God. Therefore, when he stylized every natural object he described, he kept it away from nature as far as possible. This is the reason why Islamic artworks away from naturalism and empiricism through stylization, which culminates in abstraction or formalism [3]. Spahic Omer argues that Islamic Architecture is a type of architecture that functions and (to a lesser extent) forms inspired primarily by Islam. Islamic architecture perpetuates facilities and (at the same time) is the actualization of Islamic principles. Practically, Islamic architecture is an Islamic religion that has been translated into reality in the hands of Muslims, so that it is an Islamic cultural and civilizational identity [4].

Previous research related to Islamic architecture theory and its application includes research by Mahmoud Itewi (2007), Mustapha Ben-Hamouche (2010), Rashid Kolvir Hojjatollah (2012), Behnam Ghasemzadeh, et al (2013), and Sabir Nu'man (2016). Research on the development of modern theories of Islamic architecture by Mahmoud Itewi shows that it is necessary to consider religious and spiritual aspects, form and environment, as well as the general features of modernism and originality [5]. Mustapha Ben-Hamouche, in his research on Islamization of contemporary architecture, shows that Islamization of architecture must still base on mechanisms derived from the essence of Islamic thought, and the need for a critical process of filtering and re-theorizing on contemporary architecture [6]. In his research on identity discourse in Islamic architecture, Rashid Kolvir Hojjatollah concluded that one of the most important factors in understanding Iranian-Islamic architecture in urban texture is identity. Identity elements in mosques related to urban views include domes, minarets, open and closed spaces, lights, directions, hierarchy, etc.[7]. Behnam Ghasemzadeh, in his research on symbols and signs in Islamic architecture, concluded that the style in Islamic architecture includes both secular and religious artistic styles. The most common styles are calligraphy, geometry, and flower designs, which show a high degree of complexity [8]. In his research on integrated architectural theory for Islamic architecture, Sabir Numan proposed a theoretical model in the form of four integrated elements used to guide the design process in Islamic architecture. The four elements are Pattern guidance from Allah and His Prophet (Muhammad SAW), Pattern and form from sustainable strategies and technologies, Form via sacred geometry, Regional context, and sensibilities for adaptive design [9]. Previous research above generally discusses the formulation of new theories in Islamic architecture related to modern architecture or contemporary demands and issues. The study of the design characteristics of Islamic architecture approached by looking at the ideas, values, and principles of Islam considered to be a gap of this research, so that general patterns of design characteristics can found.

The views of Seyyed Hossein Nasr and Ismail Raji Al-Faruqi, which are supported by the view of Spahec Omer, will be used as a basic theory to analyze the Islamic expression on the design and architecture of the mosque in this paper. As a cultural phenomenon, mosques in Indonesia express interpretations of Islam. The mosque is a resolution of the power play in its 
community, besides being a utilitarian building for worshipers. The evolution and transformation of mosque architectural expressions reflect the dynamic process of culture [10]. Traditional mosques in Indonesia were born and developed as a result of the interaction between social elements of society in Indonesia, Nusantara, and the world. From the physical aspect, most mosques use a multi-tiered pyramid roof supported by four pillars in the main room, while the choice of materials and the composition of the space strongly influenced by local conditions, technology, owners, and factors that influence other traditional buildings [11]. Wali Mosque architecture is an architecture that was born from a local culture or is a local cultural identity. The origin of the the Wali mosque as the Javanese mosque derived from a local public or community building type that exists in this area [12].

The physical characteristics of this Wali Mosque are a rectangular floor plan, built directly on the ground with elevated floors, a pyramid roof overlap 2 to 5, on the sidewall of the Qibla protruding outward to form a mihrab room, having a porch space at the front, the existence of a fence around the mosque with a gate, without the minarets (but using bedug and kentongan), sometimes applying a ditch or pool on the front side of the mosque or the other side, the inclusion of mausoleum as an important feature of the configuration of the mosque, the use of a pillar to support the roof construction, prayer rooms for female worshipers (pawestren) under the roof of the main hall or on the left side of the mosque [13]. The Wali Mosque considered to still maintain the authenticity of its architecture or the authenticity of its local cultural identity until now is the Great Mosque of Demak. It was proven by including the Great Mosque of Demak in the tentative list of UNESCO World Heritage Sites in 1995.

\section{METHOD}

This research is classified as a qualitative descriptive study with an interpretive approach. Interpretive research is the investigation of social and physical phenomena in a context that is quite complex, with a view to explain the phenomenon in a narrative and holistic manner [14]. Researchers do not start with concepts that are determined a priori but rather try to allow concepts to emerge from experience in the field. Library data mainly obtained from the results of previous studies with the theme of Islamic Design and Architecture, especially mosque architecture. Library data mainly obtained from the results of previous studies with the theme of Islamic Design and Architecture, especially mosque architecture. As a case study, six Wali mosques in Indonesia were considered relevant. The Wali Mosque was chosen as a case in part because the Wali mosque was the prototype of the earliest mosque in Indonesia and now regarded as one of Indonesia's cultural heritage. Visual data in the form of certain photographs are redrawn to clarify the variables to be analyzed, which are the form and meaning. Interviews were conducted with the stakeholders of the mosque to explore the meanings of the mosque's architectural elements. The results of the analysis obtained findings of the implementation patterns of values and Islamic principles in the design and architecture, especially the principle of remembrance of monotheism as well as spirituality and Sufism.

\section{RESULT AND DISCUSSION}

The Wali Mosque used as a case in this study of Islamic expression is the Great Mosque of Demak, the Sunan Giri mosque in Gresik, the Cirebon Great mosque, the Menara Kudus Mosque, the Mantingan mosque, and the tomb of Sunan Drajat. The mosque chose because it is considered to have elements that are relatively still maintained its authenticity. 


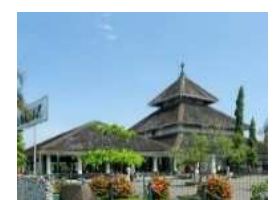

Figure 1. The Great Mosque of Demak

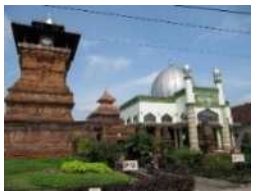

Figure 4. The Menara Kudus Mosque

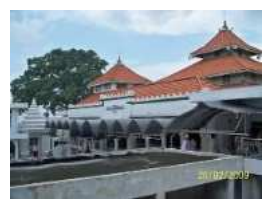

Figure 2. The Sunan Giri Mosque

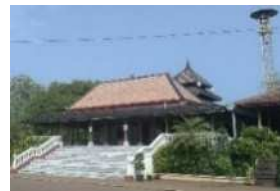

Figure 5. The Mantingan Mosque

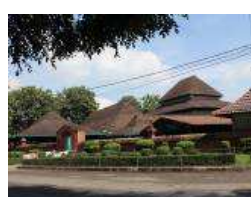

Figure 3. The Cirebon Great mosque

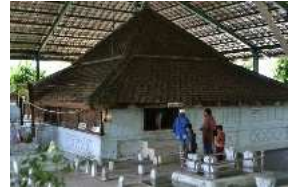

Figure 6. The Cungkup of Sunan Drajat Mausoleum

The architectural and interior elements of the Wali mosque analyzed by making interpretations of the meaning of the form considered to be able to imply a transcendence meaning that is reminiscent of the value of tauhid. Besides, the architectural elements of the mosque also analyzed the relationship between existing forms with spiritual meaning and Sufism.

\subsection{The Tawheed Remainder}

Tauhid means the ontological separation between God and all nature. Nothing in this world can reveal God. Therefore, when stylizing every natural object, it must be as far away from nature as possible. Some Wali mosques are considered to have applied the concept of Tawheed (monotheism) with the treatment of materials from building elements.

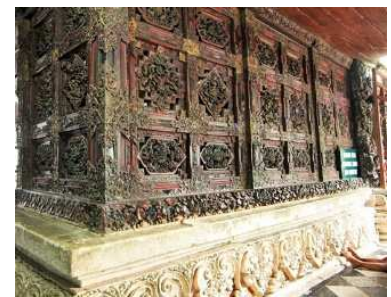

Figure 7. The wall surface of Sunan Giri Mausoleum in Sunan Giri Mosque site

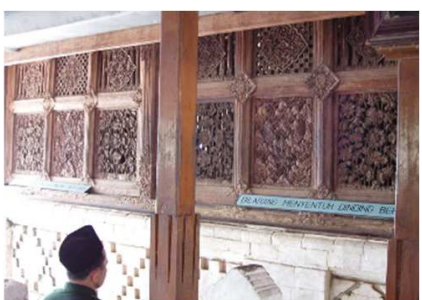

Figure 8. The wall surface of Sunan Drajat Mausoleum

The surface of the mausoleum (tomb) wall of Sunan Giri and Sunan Drajat made of wood treated with carving patterns in such a way that the characteristics of wood material are not visible and what is more visible are carving patterns with shapes that are far from their natural features. The same treatment applied to other building elements made of wood. This can found in the column in the veranda of the great mosque of Demak, the Bledeg door in the Great Mosque of Demak, the door of the main hall of the Great Cirebon mosque, the minbar of the Great Mosque of Cirebon, and the door of the mausoleum of Sunan Kudus.

Carved with all wood surfaces and colored, the characteristics of wood, especially the texture or impression of the wood surface and the original color of the wood will be difficult or even not seen anymore. The original characteristics of wood material, which is a natural product of God's creation, have been changed so that the characteristics seem to avoid creating works that are equal to God's work. 


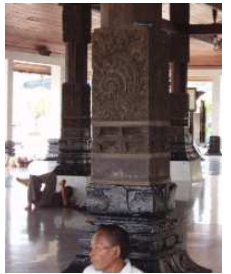

Figure 9.

Serambi column

of the Demak

Great Mosque

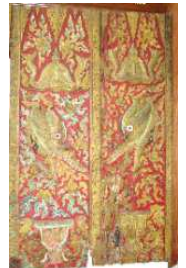

Figure 10.

The Bledeg door of the Demak Great Mosque

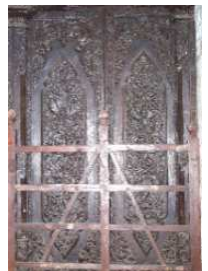

Figure 11.

The main door of the Cirebon Great

Mosque

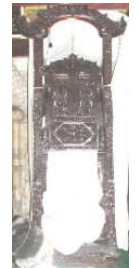

Figure 12.

The minbar of the

Great Demak

Mosque

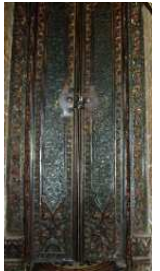

Figure 13.

The doors of the

mausoleum of

Sunan Kudus

The application of the transcendence concept that avoids similarities with nature, in addition to the wooden elements of the mosque, is also found in other elements of the Wali mosque and mausoleum.

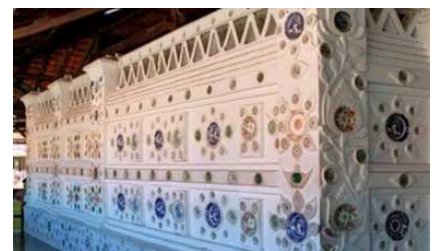

Figure 14. The wall surface of Sunan Gunung Jati Mausoleum

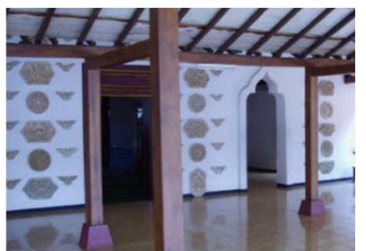

Figure 15. The wall surface of Mantingan Mosque, Jepara.

Plastered brick walls in the mausoleum of Sunan Gunung Jati and the serambi of the Mantingan mosque are examples of the application of the tawhid concept. By applying the inlay technique that is inserting ceramic material (in the mausoleum of Sunan Gunung Jati) and inserting carved wood material (on the veranda of the Mantingan mosque) has changed the impression of the wall texture. Without the inlay technique, the impression of natural wall texture is one type of material, and the surface is flat. Whereas with the inlay technique, the wall impression becomes not one type of material, uneven, and so more artificial.

From the case above, it can be seen that the application of design and architectural concepts that away from naturalism and empiricism can be done through stylization, which culminates in abstraction or dematerialization (eliminating the impression of material character). Dematerialization has become an alternative implementation of the concept of Tawheed. The expression of some architectural elements and designs of the Wali mosque looks able to provide opportunities for the perception of the dematerialization concept. The conception of design and architecture as a reminder of Tawheed is the main point of the conception of Islamic design and architecture, as expressed by Ismail Raji Al-Faruqi.

\subsection{Spirituality and Sufism}

In addition to the concept of a monotheistic reminder that culminates in the concept of dematerialization, in Islamic Design and Architecture, there are also known ideas about spirituality and Sufism. One manifestation of the application of the spirituality and Sufism concept to the design and architecture of the Wali mosque in the form of the two until the fivetiered pyramidal roof. In the Sufi world, the abstraction of monotheistic beliefs transformed to the degree of piety translated into a concept called Maqamat. The concept of Maqamat illustrates the position of a person with his God, who must take physically and spiritually. This 
concept described by conical construction. The outer ring line at the base of the cone is the symbol of the Shari'a road, the line drawn from the point on the outer circle of the base plane to the center of the base plane is the symbol of the Tarekat, the line drawn from the center of the base plane to the top of the cone is the symbol of the Ma'rifat, while the peak point of the cone is the symbol of the Hakekat [15].

The concept of maqamat by the conical construction transformed into the two until the five-tiered pyramidal roof of the Wali mosque building. The circle form on the cone base is transformed by simplification into a square form of the mosque plan because of the construction factor [16]. From the four corners of the square, a line is drawn to the top point to form a building resembling a pyramid. The form of the pyramid as a result of this maqamat transformation applied to the roof form of the main building of the mosque as a tiered pyramidal (tajug) roof with a variations number of the tire, namely the two until the five-tiered pyramidal roof.

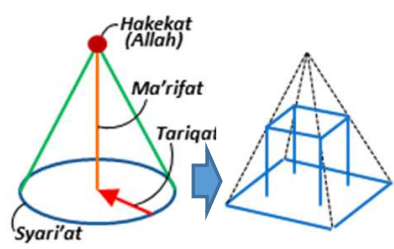

Figure 16.

Transformation from Sufism Travel (Maqomat) to Architectural Form

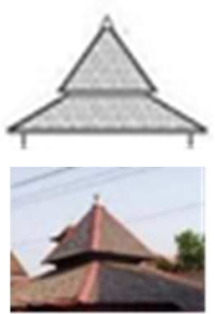

Figure 17.

The tajug roof of Panjunan Great Mosque

(two-tiered pyramidal type)

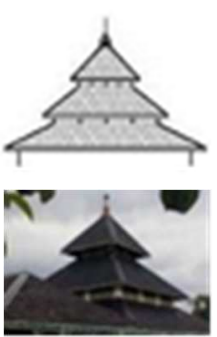

Figure 18.

The tajug roof of Demak Great Mosque (three-tiered pyramidal type)

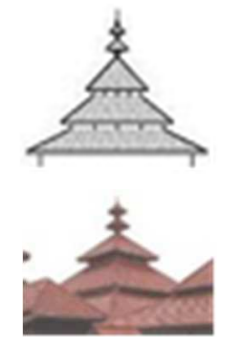

Figure 19.

The tajug roof of

Banten Great Mosque

(five-tiered

pyramidal type)

At the top of the tajug roof is placed the Mustoko element. Mustoko's forms include the results of the stilisation of pineapple in the Great Demak mosque and lotus flowers in the Mantingan mosque and Menara Kudus mosque.

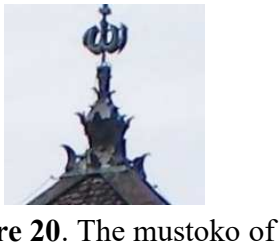

Figure 20. The mustoko of Demak Great Mosque

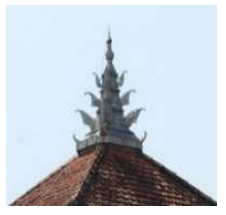

Figure 21. The mustoko of Menara Kudus Mosque

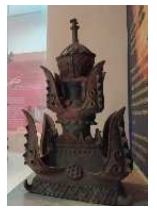

Figure 22. The mustoko of Mantingan Mosque

The form of the Pineapple chosen as a symbol because the term pineapple means as a play on the word An-Nas which means humans. So that, the meaning of the Pineapple symbol at the top of the pyramid or maqamat peak is a reminder even though our journey to God is at the peak of the Hakikat, but we are still human. While the lotus-form symbol can be interpreted as the purity of the soul when it reaches the peak level of maqamat (Hakikat). From the case of the roof designs of some of the Wali mosques above, it can indicate the application of concepts that are nuanced in spirituality and Sufism, namely the Maqomat concept. The application of the concept of maqamat means that it has raised the value of Islamic spirituality as an important aspect in the formation of Islamic design and architecture, as Seyyed Hossein Nasr argues. 


\section{CONCLUSION}

The aesthetic in Islamic design and architecture is not only the aesthetic of physical form but must be able to bring the observer's awareness to the idea of transcendence, which has meaning and function as a reminder of monotheism as the core of Islamic teachings. The expression of monotheism in the composition of shapes and spaces results from the utilization of natural objects by avoiding naturalism whose culmination is an abstraction. The application of this concept found in the interior design and architecture of Wali mosques and mausoleum in Indonesia, one of which is by removing the impression of material character (dematerialization). Dematerialization on the Wali mosque and mausoleum can be achieved in at least 2 main ways, namely by changing the texture and color of wood material on all surfaces so that the natural impression of the wood is lost or far reduced. Another way is by inlay technique that is inserting ceramic or wood material in the plastered brick surface (wall) so that the natural impression of the wall texture becomes very artificial or far from natural.

The abstraction of belief in Tawhid transformed into the degree of piety, which translated through the concept of Sufism, namely Maqamat. This conception, which illustrates the existence of a person with his God, can be transformed through architectural forms and spaces. The application of this maqamat concept transformation can found in the architectural elements of the Wali mosque, namely the two, the three, and the five-tiered pyramidal roof.

\section{REFERENCES}

[1]. Nangkula Utaberta. Arsitektur Islam. Pemikiran, Diskusi, dan Pencarian Bentuk. Indonesia: Gajahmada University Press, 2008.

[2]. Seyyed Hossein Nasr. Islamic Art and Spirituality. USA: State Univ of New York Press, 1987.

[3]. Ismail Raji Al-Faruqi. Seni Tauhid: Esensi dan Ekspresi Estetika Islam. Indonesia: Yayasan Bentang Budaya, 1999.

[4]. Spahic Omer. " Towards Understanding Islamic Architecture". Journal of Islamic Studies. Vol. 47, No. 4 (Winter 2008), pp. 483-510, 2008.

[5]. Mamoud Itewi. "Toward a Modern Theory of Islamic Architecture". Australian Journal of Basic and Applied Sciences. Vol 1, No. 2, pp. 153-156, 2007.

[6]. Mustapha Ben-Hamouche, "Islamization of Contemporary Architecture: Shifting the Paradigm of Islamic Architecture”. Journal of Islamic Architecture. Vol 1, Issue 2, pp. 70-86, 2010.

[7]. Rashid Kolvir Hojjatollah. "Identity Discourse in Islamic Architecture". Journal of Basic and Applied Scientific Research. Vol 2, No. 1, pp. 926-934, 2012.

[8]. Behnam Ghasemzadeh, et al. "Symbols and Signs in Islamic Architecture". European Review of Artistic Studies. Vol 4, Issue 3, pp. 62-78, 2013.

[9]. Sabir Nu'man. "A Unified Architectural Theory for Islamic Architecture". International Journal of Architectural Research. Vol 10, No. 3, pp. 100-112, 2016.

[10]. Bagoes Wiryomartono. "A Historical View of Mosque Architecture in Indonesia". The Asia Pacific Journal of Anthropology. Vol 10, No. 1, pp. 33-45, 2009.

[11]. Nangkula Utaberta, Kamarul Afizi Kosman \& Azimin Samsul Mohd Tazilan. "Tipologi Reka Bentuk Masjid Tradisional di Indonesia". International Journal of the Malay World and Civilisation. Vol 27, No.2, pp. 229-245, 2009.

[12]. Banbang Setia Budi. "A Study on the History and Development of the Javanese Mosque. Part 1: A Review of Theories on the Origin of the Javanese Mosque". Journal of Asian Architecture and Building Engineering. Vol. 3, No. 1 May, pp. 189-195, 2004.

[13]. Ahmed E. I. Wahby. The Architecture of the Early Mosques and Shrines of Java: Influuences of the Arab Merchants in the 15th and 16th Centuries?. Germany: University of Bamberg, 2007.

[14]. Linda Groat and David Wang. Architectural Research Methods. Canada: John Wiley \& Sons, Inc., 2002.

[15]. Achmad Fanani, Arsitektur Masjid. Indonesia: PT. Bentang Pustaka, 2009. 
[16]. R. Rahim et al., "Random and match game for education purposes with model learning technology system architecture," in Journal of Physics: Conference Series, 2019. 